\title{
ENTRELAÇAR DOS CORPOS: APONTAMENTOS SOBRE O EROTISMO EM AVALOVARA, DE OSMAN LINS
}

\author{
THE INTERLACE OF BODIES: NOTES ON EROTICISM IN \\ OSMAN LINS' AVALOVARA
}

José Helber Tavares de $A R A U ́ J O$ (UEPB)

\begin{abstract}
Resumo: Este artigo é uma proposta de investigação crítica do romance Avalovara (1973), de Osman Lins. Analisaremos o romance de Osman Lins buscando entender como a sua organização estrutural, de caráter fragmentário, produz um movimento de tensão temática em que determinados tipos de violência que implicam em sofrimento são substituídos por uma transgressão erótica mediadora de uma atitude de autonomia e autenticidade dos protagonistas. Nossa intenção é entender que a utilização da técnica de fluxo de consciência, como maneira de nos inteirarmos do que se passa na mente dos personagens, nos dá condição de perceber de maneira mais ampla que no interior do sujeito existe uma insistência dialética em expor a negatividade dos conceitos sobre o mundo erótico no qual se experimenta, fugindo de uma objetividade positiva e ontológica em favor de uma heterogeneidade negativa da consciência do ser no mundo.
\end{abstract}

Palavras-chave: Osman Lins. Avalovara. Theodor Adorno. Teoria crítica. Romance contemporâneo.

\begin{abstract}
This article is a proposal of critical investigation of the novel Avalovara (1973), by Osman Lins. We will analyze the novel by Osman Lins seeking to comprehend how its structural constitution with fragmentary aspect produces a movement of thematic tension in which certain types of violence that implicate into suffering are replaced by an erotic transgression that intermediates an attitude of autonomy and authenticity of the characters. Our intention is to understand that the use of the technique of the stream of consciousness, as a manner of being acquainted about what is going on in the characters' mind, give us condition to perceive with a wider perspective that in the interior of the individual exists a dialectic insistence in exposing the negativity of the concepts about the erotic world in which one experiences, evading from a positive and ontological objectivity in favor of a negative heterogeneity of the conscience of being in the world.
\end{abstract}

Keywords: Osman Lins; Avalovara. Theodor Adorno. Critical theory. Contemporary novel.

Os diversos modos de organização do erotismo em Avalovara, obra de Osman Lins podem ser tomados como uma instância fundamental para o desenvolvimento da linha espiral que rege o funcionamento esquemático deste romance ${ }^{1}$. Esse tema tão evidente na obra é o que

1 Avalovara, de 1973, é estruturado em blocos narrativos que se alternam de acordo com um movimento em espiral sobre um quadrado, o qual porta em seu interior o palíndromo SATOR AREPO TENET OPERA ROTAS (O lavrador mantém cuidadosamente o arado nos sulcos/ O criador mantém cuidadosamente o mundo em sua volta). A exceção das letras $S$ (que explica historicamente o esquema palindrômico que estrutura o romance) e $P$ (destinado a narrar a vida do relojoeiro Julius Heckehorn), cada letra corresponde a um eixo da narrativa da vida do protagonista Abel, escritor nordestino. Cecília, Roos e uma terceira personagem marcada apenas por um sinal gráfico norteiam os três momentos da vida do escritor que, além da busca nestas mulheres uma espécie de plenitude do amor, vive uma crise narrativa em decorrência da própria crise existencial e da incompreensão do mundo ao qual pertence. Osman Lins busca assim criar um romance sem recorrer a sistemas de organização tradicional de enredo.

Revista Graphos, vol. 19, n² 2, 2017 | UFPB/PPGL | ISSN 1516-1536 
levou, por exemplo, Moura (2009) a compreender as imagens eróticas sob a perspectiva das relações sexuais tântricas do hinduísmo, inclusive aproximando seus códigos não-verbais a símbolos dos rituais eróticos desta cultura para, assim, criar uma interpretação cosmogônica no interior dos personagens de Avalovara. Trata-se aqui neste ensaio de fornecer algumas coordenadas críticas que amplie a leitura das imagens eróticas do romance de Osman Lins. Para isso, compreenderemos a noção de erotismo tal como desenvolvida por Georges Bataille (2013) quando afirma que o momento de irrupção do erotismo desencadeia o entrecruzamento de forças contínuas e descontínuas da natureza humana. Neste sentindo, observaremos qual é a maneira que o desejo erótico se apresenta na elaboração estética do romance como transgressão negativa, instauradora de uma desordem criativa que força os limites da condição determinada dos personagens e quebra com a aparente harmonia formal da estrutura do enredo. Este processo de erotismo como uma força da interioridade humana modificadora das condições dadas somente é possível de ser percebido porque Avalovara possui um forte traço de foco subjetivo dos personagens.

Ora, como nos é dado acesso ao fluxo do pensamento, da sensação, da memória e da imaginação dos protagonistas, seja na ação imediata da comunhão dos corpos ou na lembrança mediada do passado amoroso, o romance nos possibilita adentar conjuntamente na manifestação subjetiva do desejo erótico, na poetização do outro, na busca por um objetivo que é difuso e indeterminado, mas que não se pode abandonar a tentativa de sua realização. Assim, por sofrimento surge no romance osmaniano como um fator inapreensível e capturador negativo da violência positivada exterior, o erotismo também desenvolve um papel de contato com o contraste do ser, com uma vontade de compreensão de si através da aproximação com o diferente, com o externo, com o outro. Percebe-se que esta condição tanto reflete o percurso de Abel quanto o de $\odot$ na procura de um Paraíso de confluência de desejos. Desta forma, a técnica do fluxo de consciência presente em Avalovara deve ser compreendida, na concretude do texto literário, como uma revelação patente das possibilidades históricas e naturais da experiência erótica entre sujeitos-personagens em confronto dialético com a capacidade de extrair novos significados da heterogeneidade do mundo exterior, mundo por muitas vezes rigidamente ordenado.

A sintaxe da narrativa deste romance, que se inicia com o fragmento de $\mathrm{R}, \odot$ e Abel: encontros, percursos revelações" e segue se movimentando e entrecruzando núcleos das extremidades da espiral que gira até se aproximar do ponto fixo e central denominado " $\mathrm{N}$ : $\odot$ e Abel: o Paraíso", desenvolve-se como um processo de recomposição de uma imagem erótica, 
no ápice do gozo, mas que ao fim da jornada, nos obriga a revisitar, num processo hermenêutico, tudo aquilo que aparentemente estava decomposto, invertendo o movimento da espiral. Ou seja, quando se chega ao centro do quadro sinóptico do romance, é o momento de se reestruturar todo o trajeto e toda a condição histórica que levou os personagens a confluência dos corpos: um Abel de vida sem entusiasmo criador e uma personagem inominável presa a uma forma de vida "exatificada". É pensando no advento de tal forma que Moura defenderá que a história deste romance inicia-se em N1, ou seja, na passagem central da espiral do romance em que Abel e $\odot$ atingem simultaneamente o orgasmo, plenitude e experiência da morte. Todas as outras histórias narradas são desenvolvidas como divagações fluídas da consciência que, em concomitância com este momento de encontro singular, estimula a transcendência da vida através do excesso do ato sexual.

O que temos defendido é que existe em Avalovara, dentro de uma proposição inicial quase matemática de organização do enredo, uma forma crítica que almeja exprimir o indeterminado que advém dos impasses subjetivos resultantes do movimento mental do fluxo de consciência dos personagens frente aos campos heteronômicos do mundo exterior. Este mundo exterior surge tanto no contexto presentificado pelo casal Abel e $\odot$ no ato sexual como na reminiscência do que foi vivido no passado, no contexto da convivência com Cecília e Roos. No palíndromo que tenta reger a história, há uma desestabilização do próprio modelo, como o relógio de Julius Heckehorn, o que faz com que possamos nomear tal interferência no padrão como uma expressão da negatividade, momento em que o confronto com a racionalidade exprimida no sofrimento de $\odot$ frente à Olavo Hyano ou do vazio existencial que inviabiliza a vida de Abel cria a exigência de uma projeção para a mudança do estado das coisas, inspirando a necessidade de outros estágios da condição do sujeito. Abel e $\odot$ encontram a sacralização de suas interioridades justamente na transgressão do erotismo. O romance perpassa por elementos alegóricos, simbólicos e metafóricos; devaneios e eventos insólitos; denúncias de opressão e violência; mas sem jamais abdicar do foco em detalhadas cenas eróticas, uma de suas principais perspectivas.

Vejamos como ocorre textualmente os sentidos do erotismo como constância da procura do sujeito para além de sua situação de vida gerenciada por uma ordem imposta previamente. Resgatando aqui uma aproximação com a resistência beckettiana de recorrer as fontes de indeterminação conceitual como armas para ousar não sucumbir à pura objetificação e, ao mesmo tempo, lutar por um sentido de liberdade. Partamos deste trecho central para o entendimento de como a liberdade se concretiza em Avalovara pelo desejo libidinal. 


\begin{abstract}
Abraça-me este homem (para mim se dirige há tanto tempo que não mais se recorda desde quando), uma serra mecânica corta tábuas de pinho, vai e vem no relógio e o pêndulo em forma de sistro, um vento morno move as dálias sobre a mesa, sobe da avenida um rumor confuso de veículos. Articulado na ausência e por mim mesma descrito, de maneira caótica, incompleta e até certo ponto enigmática, nos dias febris e de número impreciso em que minha boca parece saber mais do que sei, o nosso encontro alcança agora a plenitude e o final. Abel! (LINS, 1995, p.19)
\end{abstract}

Há nesta passagem do pensamento de $\odot$ a admissão consciente de que algo renovador e diferenciado está acontecendo durante seu encontro carnal com Abel. Ela ainda não sabe bem definir em graus exatos de significação, tanto assim que busca significados díspares em possíveis sons ao redor - a serra, o relógio e o vento - como que se buscasse pistas da realidade para entender o atual estado no qual se encontra, pois revela para si mesma que a noção exata do tempo pode lhe escapar. Ela sabe apenas que, na sensação do abraço, existe uma força desordenadora que emana deste encontro dos corpos e que de alguma forma vem preencher uma "ausência" em seu ser. Esta perda da noção espaço-temporal, enigmática e imprecisa, através do próprio desejo, na fusão com o desejo do outro, não é uma intensa experiência emotiva puramente interior, mas uma forte vivência do desregramento entre sujeito e objeto, fazendo com que haja uma suspensão dessa relação através da sensação desobrigada de definirse como Ser ou um não-Ser. Este fator que orienta $\odot$ para a plenitude, longe de narcisismos ou projeções, nos permite retomar a ideia de libertação do enclausuramento em si, supradeterminado pela força do iólipo Olavo Hayano, marido repressor. A sensação de nãoidentidade e a desobrigação de mimetização de si diz respeito muito mais a uma forma de extravasamento da negatividade do que uma síntese da dialética formal. Este transbordamento dos limites precisa ser indeterminado, elevados a um status daquilo que entendemos da teoria estética negativa adorniana sobre o desarmônico da estética natural.

Se pensarmos a questão da indeterminação a luz do sofrimento beckttiano, podemos retomar aqui as discussões sobre como, além do "sofrer", um traço de humanidade como o erotismo pode também exercer o papel de chave para a passagem ao negativo. Esta questão em Adorno se encontra no excurso II da Dialética do esclarecimento quando coloca Kant frente a Sade, mas que dialoga livremente com os trabalhos de George Bataille e, mais contemporaneamente, com Alain Badiou (2013). O primeiro enxerga o ilimitado na perversão sádica, os outros dois encontram uma resposta similar no erotismo e no amor. Da parte do romance em questão, como vimos na passagem acima, é incontestável que o erótico abre um caminho não apenas para $\odot$ se livrar da ordem imposta a sua vida, como também aparece numa maneira de quebra do esquematismo lógico do enredo. Insistamos também na defesa de que o desejo e o erotismo nascem de uma situação histórica e alimentam-se dela para a construção de 
um sentido heterogêneo do que é dado. Se isso pode ser comprovado dentro da narrativa, acreditamos que é avançando em sentidos enigmáticos que $\odot$, ou Abel, compreendem a sensação de "liberdade negativa" do corpo e da mente. Verifiquemos mais um trecho do romance:

\begin{abstract}
Volta-se para mim, apoiado num braço, a outra mão afagando-me a axila, volta-se, quem sabe escutarei dentro em breve no meu corpo as vozes que só ouço pela madrugada e que desde Inácio Gabriel têm sido neste mundo a minha companhia, a única, tiro a sua gravata, lanço-a para um lado, começo a desabotoar sua camisa, carros desfilam na avenida, lentos. Ouvirei aquelas vozes, o enxame de palavras que jamais distingo e ainda assim me conforta? Faz calor nessas tardes de novembro. Meu corpete negro, atirado longe por ele, pende de um bule de prata não polido, uma das meias atravessada sobre os meus sapatos, não sei onde foi ter a outra, introduzo a mão na abertura da camisa branca, sinto a sua pele, não, não a pele, antes uma força existente sob a pele, um ímã, minhas mãos deslizam sobre o ímã e não podem desprender-se, o coelho e o crocodilo saem lentamente do meu corpo, instalam-se no seu, ele recomeça a falar e a sua voz vem através das lianas, das flores e animais em que estamos ambos enredados: "Posso graduar as suas pulsações. Afasto-me de você; elas se espaçam. Ponho as mãos na sua pele; as batidas tornam-se mais rápidas e você respira mais depressa". Enquanto o ouço, enquanto a sua voz me envolve, enquanto soergo-me, desato meus cabelos, movo a cabeça, movo-a, meus cabelos desenrolam-se, frouxos, cobrem minha espádua. (LINS, 1995, p.45)
\end{abstract}

Percebemos aqui que a forma específica de indistinção move-se sob as mesmas condições em que se move o ritual sexual, ainda em seu início. O casal começa a se despir em direção a visibilidade da nudez num movimento duplo de coexistência. Isso corrobora nossa posição batailliana de que o erotismo do corpo e da mente são dispositivos que o indivíduo encontra para eliminar a sua condição de isolamento no mundo. Para Bataille, o homem como ser consciente de sua separação da natureza, ou seja, como um ponto descontínuo dos movimentos espontâneos de pertencimento ao conjunto de elementos do mundo natural, encontra-se em insulamento. O erotismo seria uma forma humana de encontrar no próprio interior dos processos de racionalidade descontinuadora uma forma de reintegra-se ao contínuo natural. $\mathrm{O}$ erotismo manifesta o desequilíbrio desta consciência limitadora, aproximando a experiência interior com a integração a algum objeto do mundo empírico, objeto de desejo e paixão. Dirá Bataille que "a ação decisiva é o desnudamento. A nudez se opõe ao estado de comunicação, ou seja, ao estado de existência descontínua. É um estado de ser para além do fechamento em si mesmo. Os corpos se abrem a continuidade possível de ser para além do fechamento em si mesmo" (BATAILLE, 2013, p. 41). No processo de se despir conjuntamente como desvendamento dos corpos para o outro, como ocorre no trecho, entre $\odot$ e Abel, entra em vigor uma entrega do ser ao outro como uma perdição de si consciente. Podemos reparar que os objetos que são lançados ao redor, como gravata, corpete e meia refletem a desordenação necessária a entrega, à ação erótica. Com a mesma função estética, as vozes que $\odot$ escuta como 
fonte de vitalidade são a representação caótica da trajetória que é sair do estado de isolamento e subjetivação, através da entrega violadora do corpo, para o estado de perturbação que o desejo erótico proporciona.

Afagar a axila, introduzir a mão no peito, deslizar a pele sobre a do outro pelo toque, soltar os cabelos, tudo está intrincado em favor de uma experiência negativa, em que não se sabe precisamente que ponto será alcançado com a desarmonia, mas que se fez necessário prosseguir. Esta desordem que captamos pelo fluxo de consciência de $\odot$, durante toda a linha O, afeta inclusive as ações do ponto de vista exterior: é a libertação das normas do Iólipo, de se sentir como ave Avalovara, de se livrar da angústia de ser duas em si, nascida e nascida, para ser dupla com o outro. Sabemos que para $\odot$ não se trata apenas de expulsar o que ficou acumulado dentro de si durante os anos, vai mais além. Vai ao encontro dos processos de pensamento constelar do corpo, de forma a ultrapassar a significação do sujeito para o campo da exterioridade da natureza: coelho e crocodilo avançam. No que diz respeito à questão literária que levantamos, o fluxo como negatividade ocorre porque ao mesmo tempo que só podemos captar a intensidade libertadora de $\odot$ na exposição da interioridade, o ato sexual erotizado através da significação do toque revela também uma experiência exterior que se inicia junto com a ação de desnudamento e, em seguida da visão da nudez. "O erotismo é a meus olhos o desequilíbrio em que o próprio ser se coloca em questão, conscientemente. Em certo sentido, o ser se perde objetivamente, mas então o sujeito se identifica com o objeto que se perde. Se for preciso, posso dizer, no erotismo: EU me perco" (BATAILLE, 2013, p.55). O desejo erótico torna difusa a relação entre sujeito e objeto, imbrica um no outro, e faz reconhecer a identificação no não-idêntico. É por isso que ambos personagens encontram uma espécie de "revelação" necessária da pulsão de vida, como encadeado na fala de Abel: "Ponho as mãos na sua pele; as batidas tornam-se mais rápidas e você respira mais depressa".

Podemos correlacionar com esse ponto algumas considerações a respeito da dialética negativa de Adorno, pois algumas de suas reflexões são fulcrais para o entendimento desta relação corpórea tão intensa em Avalovara. Adorno está preocupado com a crítica a pureza cognoscível do sujeito, acreditando que a aventura ontológica da racionalidade do ser como desenvolvimento evolutivo da capacidade civilizatória do homem levou-o a um estágio de alienação de sua relação com o mundo exterior. Tal primado do sujeito teria como sua outra face a totalidade social de um mundo maquinal, esta representada no modelo econômico do capitalismo. Para Adorno, a crença nesta centralidade do sujeito como princípio imediato emanante de significados - concepção muito próxima do que Bataille chama de isolamento na 
descontinuidade - é desmoronada quando a dimensão prática corpórea é convidada a participar somaticamente das pulsões interiores. Lá onde o sujeito tinha sua identidade cristalizada agora é necessária a reflexão sobre o que tem de não-idêntico em si e em como isso interfere em sua realidade. A técnica de fluxo de consciência expõe justamente este universo. A busca natural do prazer sexual e a luta contra o sofrimento, objetivo e subjetivo, como autopreservação, são também necessidades corpórea e, como tais, dialogam diretamente com o mundo em que se encontram contextualizados.

É por isso que o encontro de $\odot$ com Abel não é apenas uma satisfação subjetiva ou um momento fugaz de prazer. Porque, através da construção em stream, sabemos que é um rumo ao heterogêneo de si mesmo. $\mathrm{O}$ encontro dos dois e a sacralização deste encontro representam uma experiência ligada ao real: Abel encontra em $\odot$, dotada de palavras, sua obra, objeto de todo um percurso de sua crise identitária; $\odot$ encontra no corpo de Abel um despertar da vontade autônoma contra o seu sofrimento, impelido pelo aprisionamento ao iólipo. A ideia de que o corporal atua como algo essencial para o entendimento revela uma aproximação com o materialismo histórico ${ }^{2}$ e talvez seja usando esta que podemos entender que não é a erotização que qualifica o ato sexual, mas é a realização do desejo carnal que surge da aproximação do outro, como uma imagem criada na transformação constantes dos significados que entram em cena na concretude do desejo para além da relação fálica freudiana. Só entendemos o quanto é significativo para Abel "perder-se" em $\odot$ porque há um processo de rememoração por parte dele do que viveu em Roos e Cecília, assim como só é possível ver quão rica é a experiência para $\odot$ na formação das camadas de sua história, advindas do lapso entre um ato e outro de Abel.

Reconhecer tal questão pode nos levar a uma proposta de interpretação de complexa engenharia. Devemos colocar aqui a pergunta: se a espiral em Avalovara possui um movimento dialético, seria possível afirmar que partindo do centro da espiral, em N, para a sua expansão, não estaríamos admitindo que todos os eventos do romance estão conectados de alguma forma com o encontro amoroso entre os personagens? E que estes outros elementos que não são envolvidos diretamente com $\mathrm{N}$, na verdade, entram negativamente pela lembrança e suscetibilidade do heterogêneo do fluxo de consciência? Temos em Moura uma estudiosa que compartilha não apenas do argumento da centralidade do erotismo na conjunção de Avalovara,

2 A ideia de trabalho contida nos manuscritos econômico-filosóficos de Marx (2008) sobre a condição de produção não-imediata e não-instintiva do homem a partir do trabalho diz respeito a racionalização das ações do seu corpo. O erotismo é a produção espiritual que, assim como o trabalho, supera a mera necessidade instintiva. 
como também defende esta inversão da espiral. A estudiosa da obra de Osman Lins dirá: "Todas as estórias narradas concomitantemente no desenrolar do romance seriam divagações de Abel e $\odot$ entre os momentos de orgasmo e de morte. De qualquer forma, o romance começa e termina na história de Abel e a mulher feita de palavras, o que evidencia a importância do relacionamento entre os dois" (MOURA, 2009, p.83-84). Neste sentido, é importante perceber que há na configuração do fragmentário do romance um princípio amparado na materialidade dos corpos em movimento e, a partir daí um resgate de uma ampla subjetividade que não pode ser desprendido do passado histórico dos seus personagens. Em outras palavras, não é do fluxo centrado na mera abstração e interioridade dos personagens que resgata $\mathrm{o}$ ato amoroso revelador de plenitude do sujeito, pois o que nós vemos desde o primeiro fragmento do romance, na verdade, são desdobramentos de sentimentos históricos, pessoais e emocionais de um evento real, no tempo e no espaço, que recupera na interioridade o que ela tem de reminiscência das experiências. Seguindo este princípio, Osman Lins, com seu narrador organizador, faz uma recuperação sinestésica da vida e das emoções de Abel e $\odot$, no ato sexual, que é carne e subjetividade, utilizando a suscetibilidade em favor da quebra do enredo totalmente organizado. É como se um conjunto de fatos significantes da vida fosse liberados e orbitassem ao redor do entendimento dos corpos erotizados e, ao final, passassem a fazer parte da epifania do pássaro Avalovara.

As práticas sexuais, no dizer de Moura, conduzem de forma irreversível a uma mudança, "quer no âmbito individual, quer no social" (MOURA, 2009, p.53). Podemos ir um pouco mais longe nesta afirmação e dizer que esta mudança dos conflitos de ordem moral individual só ocorre em simultaneidade com o reconhecimento da mudança dos espaços de experiência. Para Abel, ressignificar o seu passado com Roos e Cecília, como dito é uma maneira de enriquecêlo e uma tentativa de modificá-lo a partir de um presente instaurador do novo advindo do encontrar-se no corpo do outro. Para $\odot$, segue-se o mesmo princípio: o corpo de Abel faz renascer o que foi um esboço em Inácio Gabriel e que o iólipo, Olavo Hayano, reprimiu. Ou seja, ambos avançam em suas suscetibilidades, e este avanço manifesta suas experiências ao mesmo tempo que gera uma nova imagem de si. Continuemos assim nossa análise do erotismo como uma força condutora de negatividade e liberação dos limites do ser:

Beijo de manso seus ombros, debruçada sobre ele, de modo que meus peitos e cabelos o afaguem, cubram-no. Sua pele recende a silêncios e manhãs. Mais frágil, o torso, do que faz prever sua cabeça; frágil, pobre de músculos, um torso de alguém pouco afeito a exercícios e sombreado de pêlos cor de cobre. Não fossem os pêlos, seria o tronco de um adolescente. Beijo os bicos escuros, ele se volta aos poucos, beijo-lhe as costelas, fica de borco e eu beijo-lhe a cintura, as vértebras, as omoplatas, a nuca. "Em Revista Graphos, vol. 19, n 2, 2017 | UFPB/PPGL | ISSN 1516-1536 


\begin{abstract}
ti, em ti, em ti", protesta o coro dos jovens, "residem toda a alegria, todas as doçuras, todas as volúpias." Beijo-lhe o ouvido e trinco a pele do seu ombro (em ti), vou cerrando os dentes como quem aperta um parafuso, aos poucos (Basia me!), ele fica tenso, mordo com mais força, os animais do tapete correm alvoroçados entre os nossos corpos (Morde me!), eu deixo de morder, passo a língua sobre a marca vermelha dos meus dentes, mordo-lhe o pescoço e introduzo a língua no seu ouvido esquerdo, aí verto sem dizê-las algumas das palavras que anseio por dizer, ele torna a mover-se e fica novamente voltado para mim. Em ti! Levanto-me do chão, olho o temporal através (LINS, 1995, p.57)
\end{abstract}

Na união sexual amorosa entre $\odot$ e Abel não existem interditos. Na verdade, eles estão ali violando e transgredindo seus interditos em favor de uma superação das suas formas de existência. Este processo de transgressão não apenas ocorre em estágios macros da sistemática do romance, ou nos graus de importância existencial contidos no desejo dos dois, mas também ocorre numa esfera microscópica, representada, por exemplo, no ato de afagar os seios, de morder os mamilos ou de passar a língua no ouvido. O beijo manso misturado a mordida, a fragilidade do corpo de Abel mas ao mesmo tempo portador de "alegria" e "doçura", cria, diferente de uma relação opositiva, uma sistemática complementar no entrelaçar dos corpos. Bataille sugere que esta liturgia erótica ajuda-nos a entender que "a transgressão nada tem a ver com a liberdade primeira da vida animal: ela abre um acesso para o além dos limites ordinariamente observados, mas reserva esses limites. A transgressão excede sem o destruir, um mundo profano de que é o complemento" (BATAILLE, 2013, p.91). Isso significa que não é um retorno a animalidade perdida ou uma volta a um primitivismo do homem, como se fossem apenas forças da natureza sexual dos seres agindo. É o reconhecimento de que o desejo é ao mesmo tempo constatação racional e pulsão de vida indeterminada e que isso leva a um encontro voluntário e complementar com o diferente. As atitudes que precedem o ato sexual entre $\odot$ e Abel fazem assim parte de um espaço de transformação dos indivíduos pela realização intersubjetiva e corpórea. Assim como o desnudamento, deixar-se objeto de prazer, representado, por exemplo, no ato de violar o ouvido do outro com a língua, é moldar-se na alteridade do outro. A automoldura de um sujeito estético, elaborado por Kierkegaard, pode resultar em subjetivação da existência. A subjetividade no erotismo, no amor e no desejo pelo outro refunda esta relação através daquilo que Alain Badiou (2013) vai entender como a ação de experimentar o mundo a partir de dois, não de um. Notemos assim que é justamente estas impressões consciente que estão presentes na nova visão das coisas que $\odot$ passa a perceber em si. O sentimento de plenitude está ligado ao reconhecimento do outro como parte de si, como liberdade de explorar ilimitadamente as fronteiras das formas de expressão corpóreas (e também linguísticas) do erotismo. 
Importante lembrar aqui que este ponto de vista conciliatório de repensar a condição das coisas a partir de dois, em Avalovara, pode ser constatada sob três vertentes não exclusivas: se a história em "O" nos fornece a perspectiva de $\odot$, a história em "R" aponta em vários momentos a perspectiva de Abel, para que em "E" e "N" tenhamos uma apresentação difusa, em que se pode pensar justamente na expressão literária direta de uma intersubjetividade moldada a dois, como bem defende Badiou. Trataremos ainda do erotismo em cada uma destas sessões. Antes disso, precisamos nos deter ainda na passagem mais intensa da linha “O”:

Como em um texto onde ecoam as penúrias do mundo, mas denso e rítmico, e escrito amanhã. És bela. Estar contigo é um dom como o de ver, como o dom de ouvir. Insensato seria estar junto de ti e não fruir o que és. Se ouço, devo agir como surdo? Não deverias nunca perdoar-me se, conhecendo-te, não te desnudasse e unisse o meu ao teu corpo eleito. Eu te amo. Tua língua, pelo desejo aquecida, recende a almíscar. Este é o odor com que a mariposa aquerôntica chama o companheiro. Conserva, pois, tua língua escondida em minha boca. Não vão as mariposas em busca de fêmea invadir a sala e unir-se à tua língua recendente, certas de que o fazem a um novo espécimen, rubro e ágil. Não vá a tua língua preterir-me em favor de alguma mariposa evocadora da morte. Como eu te amo! Perfeita em sua nudez é a vastidão celeste. Nem por isto é excessiva ou reduz sua beleza a presença das nuvens passageiras. Perfeita em sua nudez é a folha de papel ainda não escrita. As palavras com que as escureço não restringem ou diminuem a sua perfeição. Assim, também, os adereços que trazes em teu colo, em tuas orelhas, em teus dedos, em teus pulsos: nuvens na altura, palavras na alvura. Há tanto eu te desejo! Teus peitos, alvos e nédios cordeiros, vagarosamente passeiam em minha pele. Tilintam, quando se movem, seus bicos acobreados. Ouço os: guizos delicados. (...) Tomo em minha mão seu sexo alteado, sinto pulsarem a glande acetinada e as veias. O sangue pulsa, pulsa no seu sexo, no coração do sexo esse pássaro. Um frêmito: é como se tentasse fugir, escapar à pressão das minhas unhas. Um marco, o centro do corpo. Afago-o, afago docemente este obelisco, este arpão ereto e elástico, com seu focinho de lobo. Sondo, com as pontas dos dedos, dentro da carne, o seu começo ou seu fim e não o encontro, ele continua para dentro, para dentro do ventre, por mais que eu cave com os dedos não o perco, ele continua (onde começa? onde?), impressão de que prossegue pelo corpo adentro, enreda-se em caudas, dá voltas, uma planta, arbusto rijo e vibrátil incrustado no corpo deste homem, com flores nas raízes, flores e frutos, flores de um verde carregado, frutos de um rubro semelhante ao dos figos. (LINS, 1995, p.75)

Temos aqui expressões muito claras desta relação entre o erotismo e a força motriz que leva o sujeito ao excesso: fruição da existência, nudez que é "vastidão celeste", impossibilidade de sentir, na carne, começo e fim. Tais constatações dos personagens, somados ao forte processo de erotização dos corpos, de sentir o mais alto grau de violação do outro, remete-nos ao excesso de carne em movimento. Condição que serve também para mostrar que este movimento para fora de si se aproxima tanto dos movimentos que o fluxo de consciência se utiliza para incorporar o heterogêneo incessante, aditamento complementar do ato de pensar, quanto da exposição da negatividade que existe dentro do ser. O que queremos dizer é que "na base do erotismo, temos a experiência de um estouro, de uma violência no momento da explosão" (BATAILLE, 2013, p.17), e que esta rebentação expansiva do que anteriormente era uma forma 
fixa, no interior da estrutura romanesca de Avalovara, caminha para dois significados: um nos faz ver o erotismo análogo ao entendimento de origem benjaminiana, como irrupção instauradora de novas significações das instâncias captadas como fenômeno vivenciado, aos moldes de Proust. Ou seja, $\odot$ e Abel encontram na experiência sensível da realidade corporal, no reconhecer das múltiplas formas de sentir a si mesmo no toque do outro, uma forma de construir uma nova identidade. Por isso esta sensação de êxtase que conduz para a liberdade. $\mathrm{O}$ outro significado tem a ver com a questão formal. É a sensação de embevecimento pelo qual os personagens passam e que, na febre do desejo, sabendo não poder conceituar precisamente em termos um significado, lançam mão de formas irreais e não-conceituais. O casal sente-se fascinado por um mundo impreciso e disforme que garante a certeza de que a forma de vida anterior, que era inadequada para $\odot$ e indiferente para Abel, já não estão mais presentes. Este momento significa uma brecha no evento preenchido com sua negatividade: $\odot$ e Abel fazem amor sob um tapete que é somatizado ao evento. Suas figuras são lançadas de maneira insólita como um transbordamento de sentidos, como indeterminação e momento particular em que a falta de nexo torna-se compreensível pela sua incompreensibilidade. Deste modo, a linguagem que representa o pensamento de $\odot$ ' é portadora desta pulsão incomum, busca-se incessantemente criar um entendimento da experiência que não é mais individual, ou seja, que "estoura" para fora de si ao encontro do diferente.

Adorno dirá que "a beleza do colo e o torneamento dos quadris agem sobre a sexualidade não como fatores a-históricos, puramente naturais, mas como imagens que encerram toda a experiência social. Nesta experiência está viva a intenção de algo diverso da natureza, o amor não limitado ao sexo" (ADORNO, 1985, p.103). Trata-se de uma afirmação central para o entendimento de que, na análise literária, os fatores históricos resgatados da experiência são incorporados ao pensamento como lapsos de rememorações profundas. Somado a isso, a imagem da beleza corpórea erotizada só pode ser formulada do constructo de uma linguagem poética. Parece-nos que Avalovara é um romance que tem este recorte singular muito próximo desta proposição adornianas: amor como fio de condução para a alteridade e que se manifesta tanto no corpo como elemento empenhado na prática real quanto no caráter moral. É significativo perceber isso na perspectiva de Abel, representada nas duas passagens seguintes:

Encho a boca com o bico do seu peito e sugo-o, sendo como se bebesse a vida de $\odot$, suas paixões e acidentes. Surgem, intercaladas no seu discurso, palavras que conheço e apraz-me supor que pertencem à mesma frase, desarticulada, enlaçada com outras, numerosas: um corpo desmembrado. Pouco a pouco, o idioma em que me fala e com o qual, talvez, caçando o não-caçável, amplie e encante o mundo, retorna ao limbo onde é fabricado. Inversamente, as palavras de uso claro vão ocupando o campo do 
discurso, desfaz-se a possessão ou demônio verbal e $\odot$ revela-me, não com minúcias e clareza, mas de um modo críptico e simbólico, como se lesse, ubíqua, nas mãos que visse entre as suas, o próprio destino, revela-me o que da sua vida acredita saber e o que sabe. Ama-se o que em quem se ama? O que, em quem amamos, faz com que o amor se manifeste? O ser (visível) ou sua história, que ouvimos? $\odot$ e eu ante o eclipse: leio no mundo e sou instruído, sem palavras, sobre os olhos que me espreitam de dentro dos seus olhos. (LINS, 1995, p.194)

A verdade tem sempre um fundo falso onde se esconde uma palavra ou evento essencial. Aí reside a nossa integridade, o nó dos laços, o encontro das forças, o centro do secreto, o verdadeiro Nome nosso. Aí não chegarei e nem ela admite. Repete-se e povoa-se, abre, até onde pode e suporta, o seu arcano, leva-me, vai, introduz-me, sem ostentação e sem pudor, num mundo jubiloso, convulsionado, fragmentário, duro, sujeito à decifração e não esconde os seus lixos. Por que o faz? Ama com tanto fervor a verdade? Recusa-se a ceder-me um corpo sem história - o que seria ceder um objeto sem ilações e neutro? Crê nos exorcismos a ponto de supor que os incidentes lastimáveis nos quais se lança por decisão e cálculo deixam de existir à medida que os esconde? Os fios, enlaçando-se, formam a renda. Emaranhados, nada expressam e tendem a partir-se. (LINS, 1995, p.194)

Sugar os seios de $\odot$ como quem absorve determinação e indeterminação é um ato de pertencimento, uma indistinção entre posse e entrega. Temos então no primeiro trecho uma série de imagens que remetem a este direito a um movimento dissociativo, que infringe o estado dos personagens de uma condição estritamente de subjetividade ontológica - de uma consciência humana em si - para um ser mediado de forma contingente ao outro: "acidente", "desarticulada", "desmembrado", "caçando um não-caçável”, "de modo cripto e simbólico". $\mathrm{Na}$ sequência do trecho, a consciência de Abel diante da instantaneidade vivida no corpo de $\odot$ passa a perscrutar este sentimento múltiplo do qual é espontâneo e livre, em que as incertezas, em forma de pergunta, giram justamente em torno da procura de um objeto amado e que não pode ser encontrado com uma precisão ideal. Assim, a palavra interior, enquanto fluxo de consciência, é em diversos momentos coerente, mas move-se cegamente rumo a uma nova forma de personalidade, ainda não delimitável.

Recuperando novamente Alain Badiou, "o amor não é simplesmente o encontro e as relações fechadas entre dois indivíduos, e sim uma construção, uma vida que se faz, já não mais pelo prisma de Um, mas pelo prisma de Dois. E é o que chamo de 'cena de Dois"” (BADIOU, 2013, p.24). Atentemos então para o fato de que, na visão do filósofo francês, o amor não é uma síntese onde há uma transformação do que era dois em uma unidade, numa relação junção dialética hegeliana. Há uma dialética negativa em que uma das partes reconhece a presença do outro em si e fora de si, inviabilizando partição positivo/negativo/convergência. A experiência amorosa assim é a possibilidade de vivenciar e significar o mundo em conjunção. Como que uma lenta construção de sentido do mundo a partir de uma mediação dupla: a primeira mediada pelo erotismo, propulsão exterior que busca recriação da vida um no outro; a segunda, como 
entendimento de que suas significações são uma construção de sujeitos sociais. Em ambos os casos, há o princípio da materialidade, seja corpo, seja história. É por isso que Abel pergunta para si mesmo, em pensamento, se ama $\odot$ em sua forma imediata ou em sua história.

O segundo trecho apresenta claramente esta elaboração em "Dois" proposta por Badiou e que nos ajuda a interpretar o encontro do casal a partir do seguinte fundamento dialético: a relação entre $\odot$ e Abel é superação de si e complementação do outro. É por isso que Abel encontra sua epifania de vida em $\odot$ e ela a sua liberdade em Abel. Além disso, nada mais auxiliar ao entendimento negativo do que passagens em que expresse que "a verdade tem sempre um fundo falso onde se esconde uma palavra ou evento essencial". O mundo "jubiloso" e "fragmentário" que o envolver dos corpos funda no desejo fluído, exposto literariamente no pensamento do personagem, é uma entrega que pressupõe uma história. A menção a um exorcismo como purificação de uma história traumática significa também a liberação, de forma transgressiva, do que há dentro de si, "sem ostentação" e "sem pudor" do que estava interdito, silenciado, guardado involuntariamente. É possível assim chegar a constatação de que, no espaço do romance destinado a relação entre $\odot$ e Abel, a perspectiva que é adotada para a libertação dos dois personagens no plano amoroso em nenhum momento aponta para unidade, mas sim para o erótico como fissura da forma de vida determinada em si e para a instauração do amor como Dois, sujeito composto de identidade e não-identidade.

Podemos aqui citar Alex Honneth (2003) e sua interpretação do amor a partir de uma teoria do reconhecimento. Discutindo Hegel e George H. Mead, Honneth desenvolve uma teoria de que as ações no plano da vida social exigem do sujeito que ele busque formas de reconhecimento de sua moral através do pressuposto da interação com o outro. Isto é, há uma necessidade imperativa de estar em comum com o outro e que não é constatada apenas na ação e seus desdobramentos consequentes, mas na significação e aceitação da parte de outros indivíduos como forma de autorrealização. Expresso de outra maneira, nenhum sujeito consegue alcançar sua autorrealização em si, sem o reconhecimento do outro. Honneth acredita que este reconhecimento advém de três maneiras: do amor, do respaldo jurídico de uma moral e do princípio altero da solidariedade. Interessa-nos aqui sua concepção de amor:

Sem a segurança emotiva de que a pessoa amada preserva sua afeição mesmo depois da autonomização renovada, não seria possível de modo algum, para o sujeito que ama, o reconhecimento de sua independência. Uma vez que essa experiência tem de ser mútua na relação do amor, o reconhecimento designa aqui o duplo processo de uma liberação e ligação emotiva simultâneas da outra pessoa; não um respeito cognitivo, mas sim uma afirmação da autonomia, acompanhada ou mesmo apoiada pela dedicação, é ao que se visa quando se fala do reconhecimento como elemento constitutivo do amor (HONNETH, 2003, p.179) 
Esta leitura do amor nos parece muito próxima do que encontramos na linha $\mathrm{E}-{ }^{\circ} \odot \mathrm{e}$ Abel: Ante o Paraíso". Nela, podemos identificar o fluxo de consciência de Abel durante a ação do ato amoroso e as significâncias múltiplas e sensações indefiníveis que são registradas sob ótica da heterogeneidade estética da forma, algo inerente do fluxo:

\begin{abstract}
Amada: quando incontáveis seres conhece e cruza o homem sem que seu próprio ser se amplie, avance e alcance, tu me conduzes (para onde, para onde?) e não casualmente rondamos nós os limites deste bosque no qual perpassam aparições. Afluentes e afluentes, muitos desde sempre e para todo o sempre insuspeitados, formam o nosso encontro. Desnudamo-nos, imersos em mútua ebriez lúcida. Ah, fosse o vestíbulo do nosso prazer, também, o da unificação e do conhecimento! (...) Também te amo por isto e ainda pelos vultos femininos que integram, vívidos, a tua substância, a ela acrescentando uma qualidade plural. Tu: estuário. Amando as convergências, o que de convergente há no teu ser havia de atrair-me. Isto, amor, é tudo? Não e não saberei, com clareza, por que te amo e não poderei alcançar todos os motivos e sentidos deste encontro, numerosos e talvez até contraditórios. A decifração, afinal, seria a prova de que tudo — nós e nossos passos e esta hora dispensavam existir. (LINS, 1995, p.327-328)
\end{abstract}

Este plano do que não se pode ser apreendido em conceitos é refletido na forma do que Honneth chamou de "duplo processo de uma liberação". Abel encontra-se em $\odot$, nela, amplia as noções de si, avança na plenitude do amor e da palavra, alcança no que procurava dentro de sua suposta ontologia uma essência que estava fora dela. Rondam os dois "até os limites deste bosque", ou seja, vão até onde o prazer erótico pode permitir conhecer e autoconhecer. Também é uma definição feliz a noção de amor como "ebriez lúcida", pois recupera abertamente tanto os contornos racionais quanto sua dialética com o que nega: o conhecer através da nãoidentidade, o difuso como experiência diversificada do reconhecimento amoroso, sentido no erotismo que excede as noções racionais. É por isso que, no trecho destacado, Abel não sabe precisar - "não saberei, com clareza, por que te amo e não poderei alcançar todos os motivos e sentidos" - que amor é este, mas sabe que há um ser que pode chamar de amada, que lhe restaura autoconfiança.

Poderíamos assim perceber que Badiou, Bataille e Honneth guardam, em suas respectivas teorias, proposições em comum com a negatividade da filosofia adorniana do sujeito. Em nossa hipótese, poderíamos definir, a luz de Adorno, este argumento da seguinte maneira: Abel não existe como um ser, sem o ente $\odot$. Refletida nos outros autores, pode-se dizer que encontramos semelhanças na integridade moral interior através do reconhecimento mútuo, em Honneth; na erotização do outro como ida ao encontro de uma continuidade perdida e a uma nova forma de agir, em Bataille; no amor como intersubjetividade em comparticipação no mundo, em Badiou. Em todos estes três casos, o princípio de associação íntima entre sujeito e objeto e seus graus de significação - constatados pelos próprios personagens, como no trecho 
acima - dizem respeito à inviabilidade de uma unidade sintética de opostos e de uma insistência em não se deixar atomizar na individualidade de um ser abstrato. Assim, chegamos a um pressuposto fundamental da dialética negativa, em que a tese contem em si o seu contrário ocultado, ou seja, o ser já tem um componente formativo da materialidade histórica do objeto que não pode ser mensurável por meios de uma concepção objetiva, mas por uma constatação de que há um excesso de si, auto-controlado, que exige a experiência de contato com o outro para alcançar a sua identidade social. Isto fica bastante evidente em um trecho fundamental do romance, na linha "E" - $\odot$ e Abel: Ante o Paraíso - em que Abel constata a presença de parte de sua identidade que não se expressa em uma imagem limitada do seu presente, pois o que se sente nos gestos eróticos do ato amoroso é o movimento de violação de si na violação do outro e que não é acessível claramente na forma discursiva: “As representações são sempre enigmáticas, alusivas, fracionárias e quase nunca contempladas na sua totalidade. Como introduzir com ordem, num espaço forçosamente limitado, tudo que pretendemos?" (LINS, 1995, p. 309).

Este pensamento de Abel é a constatação de que, através da experiência do erotismo, ele desautomatiza os processos de limitação do ser dos quais se fazia presente em sua vida até a chegada de $\odot$ e, ao mesmo tempo, o sentir dos corpos e mentes se transforma em instrumento do desejo para quebrar e fracionar a dominação da qual a personagem inominável era submetida. Chegamos assim ao entendimento de que, na intensidade da manifestação do erótico, há uma energia que garante um "direito a errância” que podemos também tomar como forma estética de desestruturações constantes do interior do sujeito em nome de uma outra maneira de se perceber como indivíduo, tendo como primado a aptidão de instituir relações com o heterogêneo. Assim, quando falamos de reconhecimento de uma alteridade como forma de constituição heterogênea de si estamos em rumo a negatividade e compartilhamos da angústia do questionamento de Abel: como obter a consciência daquilo que simultaneamente está sendo decomposto de minha identidade e está brotando como algo de novo ainda não entendido e indeterminado?

A solução estética criada pela mente dos personagens é através da expressão do irrepresentável como um colapso da representação. As figuras do tapete sobre o qual se amam passam também a serem incorporadas no jogo dos corpos de modo a serem um intensificador da epifania subjetiva. Não somente isso, mas por exemplo, $\odot$ é transformada em palavras, de onde segue uma necessidade de expressar este colapso já antecipado pelo teor inominável da qual é portadora. Além disso, há ainda as sensações de espacialidade e temporalidade que são 
tragadas para dentro do espaço do tapete. O insólito passa a fazer parte da narrativa mais uma vez, mas agora com uma intensidade progressiva, somado ao "fenômeno novo" de descoberta e superação:

O mal das coisas espantosas é que nos subjugam, arrastando-nos para as suas leis e natureza - e assim o nosso espanto, em face de um fenômeno novo, nunca ultrapassa os limites usuais: mágicas e monstros, afinal, pertencem ao nosso mundo e só o que nele não ingressa é realmente assombroso. Ofuscado e sentindo vacilar o chão sob os pés, levo as mãos à cara e por três vezes tento ver e a vista se desanuvia. Corpos desmesurados e leves como nuvens, velozes como pássaros, compactos, deslizam entre si e se aproximam do vale, sem ruído de nenhuma espécie e sem que se movam o cajueiro e as canas; o mundo estático. As sombras dançam na paisagem - grandes como pastos, açudes, boiadas - e os primeiros corpos descem ou abatem-se, torres e jardins, escadarias, esculturas, pórticos, uma cidade, a Cidade um dia anunciada, buscada, cujo encontro obseda-me e por fim se revela, se ordena, simula, violando espaço e tempo, uma forma particular de existência e alivia-me o fim da busca: à luz do meio-dia, descortino-a. (LINS, 1995, p.347)

Em um determinado momento da seção haverá um entrecruzar de focalização interior, fazendo com que possamos obter uma imagem da sincronia existencial de Abel e $\odot$. Mais ainda, há também um adicional de parágrafos que são construídos com um narrador onisciente, o que pode remete a ideia de que o constructo narrativo também pode estar concentrado na indeterminação fracionária e libertadora que marca a experiência erótica dos personagens. Plano de expressão e plano de conteúdo regimentam uma mesma proposta: dissociação da determinação. Enquanto os personagens avançam para a descoberta de uma forma muito peculiar de estranhar a si mesmo no espanto causado pela intensidade da experiência sexual com o outro, abandonando a posição de sujeição e fenecimento - por parte de $\odot$ - e de insulamento e vazio - por parte de Abel - esta descoberta recusa a entrar no plano representativo de uma linguagem conceitual mensurada com precisão e objetividade. Ela, na verdade, é apreendida também sob um caráter ora enigmático, ora decomposto em uma forma de discurso desordenado. Um parágrafo como o citado abaixo é bastante elucidativo desta percepção de que o erotismo é uma liberação da vida que passa a alterar a forma de agir, sentir e julgar:

Ela e ela, tu, o acesso, ó corpo mágico, ó glória e privilégio desta travessia, em quantas superfícies cruzadas reflexas opostas afundam falo e Abel, espaço de vozes e vozes e vozes e vozes, múltiplas bocas múltiplas, nossas línguas um laço, o ar que expira e seu odor ácido e quente, jasmins abertos Sol meio-dia, outro sexo oculto no seu sexo mastiga a glande atônita, exaure-se a cantata e cresce, entre súplicas e gritos, o compasso do relógio, Julius os engenhos conjugados de som, uma criança e um cão caberiam na caixa de madeira, Heckethorn, ventos ligeiros tapete bosque canto festivo de aves, meu nome se enuncia em algum ponto, dos corpos? meu nome um centro?, o Portador e o curto relâmpago sobre os edifícios, ela grita o meu nome prende o meu rosto, arrebatada e enérgica, o nariz mais nítido e os lábios inchados e lépida chama rubra a língua e os quatro olhos abertos, cruza-me e rega-me, Abel, vê como te recebo e como te festeja a minha carne, ai, não mais o vilipêndio não mais a ofensa não mais o corpo solitário não mais, vem e cruza-me em triunfo com a tua vara florida, pertenço-te sem normas e sem exigências e abro ao teu ingresso tudo que sou e hei,

Revista Graphos, vol. 19, n² 2, 2017 | UFPB/PPGL | ISSN 1516-1536 
amo-te-amo-te-amo-te-amo, os cordeiros e seus guizos, os insuportáveis gumes do teu rosto, contemplo-o e beijo as aréolas, maiores os pêssegos e mais escuros, doces, tenros, maduros, curva a minha cabeça contra os peitos, a sucção, os beijos, a pele machucada entre os lábios e os rápidos signos esquivos que assomam nos bicos retesados, rápida multiplicação como se lanternas nascidas no seu corpo, mágicas, iluminando-a, reflexos?, emblemas?, insetos?, contas de vidro?, débeis lâmpadas veladas dentro do seu corpo, o grito acidulo do pássaro, afloram os signos e fermentam, vivos, os signos, outro corpo no seu corpo, lutam e devoram-se, nada amenos ou plácidos ou domesticáveis, enxame cambiante e rosnador, com sua força de dentes e seu fogo de pederneiras feridas com aço, indisciplinado combate, ela em si oculta, ela e ela, o vento e seu alto do báculo, alto, alegrando o centro do meu ser o cotovelo esquerdo para cima e a mão à altura do rim afago a planta sedosa do seu pé, seu calcanhar polido, ela alteia mais a perna em direção ao lustre, trança os pés nas minhas costas e nosso mútuo olhar, afetuoso, é também grave e atento, cada rosto uma inscrição, o destino ou o azo do outro, a chave, o veredicto, a alternativa, a carta de baralho, a estrela, a sorte. (LINS, 1995, p.347)

A força da relação entre o casal dilacera a constituição formal da narrativa. O que nos é apresentado no trecho acima, de Avalovara, é que há uma consciência em "Dois", isto é, há uma realização digna de felicidade no processo de reconciliação consigo mesmo encontrado na afetividade e erotismo do outro. Isso está representado em uma forma transgressiva em que se expressa em um acordoamento de narradores. Não existe unidade narrativa, o trecho contém "múltiplas vozes" que hora rementem a Abel, ora a $\odot$ e hora a um narrador em terceira pessoa que aparece como uma visão "fora de si" de ambos. Este talvez seja o ponto experimental de Osman Lins que se encontra no cerne da nossa exploração da relação entre identidade e nãoidentidade: a consciência do prazer como transgressão, a luta por uma vida autêntica, a consciência moral pautada na alteridade intersubjetiva, o reconhecimento da formação e construção de si através da experiência sagrada do erótico com o outro, todos são fontes de uma forma de libertação e ruptura de qualquer visão de sujeito determinado somente por sua subjetividade. Aqui a imagem se mostra com uma força de alteridade quase que insuportável, as passagens eróticas da linha 'E' de Avalovara possui um máximo denominador comum de relação com o outro, catalisado na experiência amorosa que não é nem meramente toque sensível, nem satisfação interior narcísica.

O erotismo em Avalovara libera a não-identidade dos personagens, que estava contingente devido a um outro contexto de significações históricas destes indivíduos, mas que agora podem se entregar ao gozo de suas plenitudes e ir em movimento a um Eu-renovado. Não é à toa que comumente esta situação é denominada como crise de identidade, a diferença neste romance é que esta crise de identidade é transgredida. O fluxo de consciência de ambos aparece assim no romance como essencial para captar este movimento da consciência sensível e desta transformação interior/exterior vivenciada por Abel e $\odot$ : 
O que na carne de $\odot$ clama por liberar-se - tensão de mola presa, ânsia dominada, explosão latente na neutra aparência da bomba - é a sua beleza em outro plano, mais depurado? Escapa dos meus braços e senta-se sobre as pernas, meio apoiada nos longos dedos ágeis sem anéis, de frente para mim, réplica, em outro plano, da luminosidade íntima que vibra em tudo. A fronte estreita não parece mais alta, o arco das sobrancelhas, sim, revela certo espanto e os olhos fitam-me com um brilho quase insuportável entre as pestanas grossas, mas o nariz é o mesmo, reto e pontudo, apenas mais distendido e com as asas afiando, nenhuma alteração no contorno dos lábios, abertos como se nunca lhes bastasse o ar, talvez esteja mais branca - ou mais luminosa? - e se acho mais compactas as deslumbrantes volutas dos cabelos, onde se fundem ouro e aço, deve ser porque estão soltas, desfeitas, em desordem, fios úmidos colados à depressão entre os seios. Alterações nas curvas da cintura e das ancas transbordantes, no volume dos peitos, no torneado dos braços, na grossura das coxas? Nenhuma. Contudo, grandiosa, o rosto insubmisso meio oculto na massa dos cabelos, as mãos tocando ligeiramente o tapete, ela é a mesma e outra, ela transformada e intensificada, havendo, entre a mulher que entra na sala ainda escura e esta, respirando rápido e brilhante de suor, a distância existente entre uma faca cega e a mesma faca afiada: sua beleza, agora, tem gume de navalha. (LINS, 1995, p.342)

Com certeza, algumas questões que diz respeito à importância do erotismo em Avalovara podem ficar em aberto para um aprofundamento, inclusive nas minúcias das imagens. Tarefa de trabalhos vindouros. Longe de seu esgotamento, é um tema que exige uma pesquisa que só tende a enriquecer a obra em desdobramentos de leitura. Como vimos, a abordagem do erotismo é central para o entendimento da forma de vida dos personagens, da evolução do enredo fragmentário, da narração em fluxo de consciência. A tentativa de mostrar que os modos de apresentação da consciência dos personagens no momento de erotização e transgressão são fundamentalmente passagem para a não-identidade, para a negação de uma ontologia do ser e que se manifesta para além de um narcisismo ou uma projeção no outro. Manifesta-se exatamente ao contrário disso: na possibilidade do sujeito se redefinir sob aquilo que está presente em si mas que é reconhecido como deferente de si. Estamos assim diante do amor entre $\odot$ e Abel que não se coloca positivamente como um discurso objetivo, mas que exige uma forma conveniente de expressão da sua indeterminação. Pensado de outra maneira, podemos afirmar que o erotismo no romance em análise é uma porta para o entendimento de uma dialética negativa vinculada aos movimentos do fluxo de consciência. Se o sofrimento pode aparecer como característica humana que se apresenta como físico e psíquico - que nos coloca na condição de ser e de ente - o amor/erotismo possui as mesmas propriedades metapsicológicas: pulsão, desejo, erotização e sensibilidade corpórea estão sob o mesmo fenômeno. O que o fluxo de consciência, com sua heterogeneidade estética faz, é um processo de formalização do saber sem a necessidade de uma conceitualização racionalista precisa, pois trabalha com liberação de indeterminações. 


\section{Referências}

ADORNO, T. Dialética do Esclarecimento. São Paulo: Jorge Zahar, 1985. . Dialética Negativa. São Paulo: Zahar, 2009. . Notas de literatura I. São Paulo: Duas Cidades/ 34, 2003. . Teoria Estética. Lisboa: Edições 70, 2008.

BADIOU, A. Elogio ao amor. São Paulo: Martins, 2013.

BATAILLE, G. O erotismo. São Paulo: Autêntica, 2013.

BENJAMIN, W. Obras escolhidas. São Paulo: Brasiliense, 1994. 3v. Origem do drama barroco alemão. São Paulo: Brasiliense, 1984.

HONNETH, A. Luta por reconhecimento: a gramática moral dos conflitos sociais. São Paulo: ed. 34,2003

KIERKEGAARD, S. Os pensadores. São Paulo: Abril Cultural, 1979.

LINS, O. Avalovara. São Paulo: Companhia das Letras, 1995.

MARX, K. Manuscritos econômicos-filosóficos. São Paulo: Boitempo, 2008.

MOURA, F.B. Serpente em espiral (o movimento do erotismo em Avalovara). São Paulo: USP, 2009. 